tudinally, whereas in all the others it is more or less convex longitudinally, the costæ of the sulcature also are much shorter than in its allies. Antilope can then be separated off by the concavity of the metathorax above the insertion of the body, which is distinctly shining, whereas in the others it is quite dull. We are then left with 3-marginatus, 3-fasciatus, parietinus, and pictus. Trifasciatus may be known by its long thorax, the mesothorax being longer than wide across the tegulæ; 3-marginatus differs from the other two in having only three abdominal bands; finally, parietinus differs from pictus in having the 1st segment of the body narrower, and its band largely and suddenly dilated on the sides, while in pictus the bands are all linear.

The third section (Symmorphus) has three species: crassicornis may be known by its larger size, smooth and almost impunctate sides of the mesothorax; gracilis has many abdominal bands, the thorax truncate in front, and its angles mucronate; sinuatus has only three abdominal bands, the thorax rounded in front, and the angles not mucronate.

Mr. Bridgman first called my attention to parietinus, and remarks that there is a first-rate figure of it in Curtis's British Entomology ; there is no doubt, I think, that all the species are good and distinct, they only want a little careful examination.

Holmesdale, Upper Tooting :

February 13th, 1879.

A NEW EUDROMUS, AND THREE NEW SPECIES OF LEPTURIDAE FROM MADAGASCAR.

BY H. W. BATES, F.L.S.

In the few remarks I published in the January number of this magazine on the remarkable carabideous genus Eudromus, I alluded to the probability that more species yet remained to be discovered on the highlands of central Madagascar. It so happens that the next collection arriving in London from that island contained a strikingly distinct and beautiful new species of this genus, which I take this early opportunity of describing.

In the same small collection, and in a previous one of similar character, the extraordinary Lepturide of Madagascar were well represented; there being, besides Sagridola maculosa (Guér.) and Logisticus rostratus (C. O. Waterhouse), three new species of large size, one a new genus, the descriptions of which are here added. 


\section{Eudromus LUCIDIPENNIS.}

Niger, politus, sub-opalescens: thorace sub-cordato, angulis posticis rotundatis, lavissimo, sulcis tribus modice impressis : elytris elongato-ovatis, humeris nullis, carina laterali valde elevata costisque utrinque quinque obsoletis, apice simplicibus : tarsis (ठ ) omnibus subtus dense setosis.

Long. 15 lin., 8 .

Very distinct from the allied species by the polish of its surface, which appears as though varnished, and above has opalescent reflections. The elytra are destitute of humeral angles, which are more completely obliterated even than in Eu. striatocollis. The eyes are rather more prominent than in that species, and the posterior orbits less tumid. The thorax is sub-cordate, but much less sinuated and narrowed behind than in Eu. striatocollis; there is, however, a distinct sinuation in the sides, preceding the blunt and almost rounded hind angles; the surface has a long shallow groove (the prolongation of the basal fovea) on each side the dorsal furrow. The lateral carinæ of the elytra are so prominent, that the epipleuræ towards the base are almost vertical; they are also reflexed, making the sides of the elytral surface longitudinally concave; the interstices between the indistinct costæ are excessively smooth and glossy.

Madagascar: one example, $\widetilde{\sigma}$, for which I am indebted to $\mathrm{Mr}$. George Lewis.

\section{ANTHRIBOLA, nov. gen. (Lepturide).}

Gen. Sagridolæ affinis. Caput elongatum, ante oculos rostriforme, haud dilatatum: tubera antennifera haud elevata, fronte subplana; oculi ovati, haud emarginati, oblique positi, prominuli, subtilissime granulati. Antenne corpore breviores ( + ?) graciles, filiformes, media fronte ionge ante oculos inserti; articuio basali fere lineari quam 2-4 conjunctis longiori. Thorax subcampanuliformis, ut in Lepturis, sed dorso leviter bigibboso. Elytra trigona, ad suturæ apicem paullulum dehiscentia, apice sinuato-truncata, extus spinosa. Pedes sub-breves, robusti, femora intermedia et postica subtus acute dentata; tibia recte, tarsi haud elongati.

A remarkable form, much resembling Sagridola, but differing in the elongated parallel rostrum and slender antennæ, with elongated scape, \&c.

\section{S. DECORATUS.}

Supra ochraceo-pubescens, capite thoraceque supra vittis duabus, elytris fascia sub-basali maculari, alteraque postmediana utroque disco postice dilatata, humeris et marginibus nigris; epipleuris nudis nitidis, testaceo-fulvis; pedibus antennisque nigris.

Long. 9 lin., ㅇ??.

Madagascar. 


\section{Mastododera coccinea.}

Magna, robusta, rufa; elytris paullo rufo-velutinis exceptis, nuda ; prosterno medio, mesosterno et coxis omnibus nigris; capite fere ut in M. nodicolli, oculis minoribus colloque crassiori; antennarum scapo subclavato: thoracis tuberibus quatuor dorsalibus fere aqualibus, tubere laterali magno, paullo curvato: elytris amplis, apice integris, supra basin versus punctulatis; tarsis posticis articuli basali triangulari haud elongato.

Long. 18 lin., ? .

The colour of this large and conspicuous insect is nearly that of red sealing-wax, including antennæ and legs; the black portions are confined to the coxæ and the surrounding parts of the sterna.

Madagascar.

The thorax is impunctate, and, like the rest of the body, slightly shining. Some patches of silky pubescence on the elytra have, in certain lights, a beautiful rosy tint.

\section{Mastododera difformipes.}

M. nodicolli angustior, capite, corpore subtus, antennis et tibiis nigris, thorace sanguineo, elytris fulvis subglabris margine laterali et sutura anguste nigris: pedibus posticis (pracipue tarsis) elongatis, tibiis apice intus subito dilatato-sublobatis, tarsis testaceo-flavis; femoribus omnibus rufo-castaneis basi nigris, tarsis 4-anticis nigris. Long. $10 \frac{1}{2}$ lin., ơ.

The head is more elongated in front of eyes, and the base of the antennæ proportionately more remote from the latter than in $M$. nodicollis; but the shape and granulation of the eyes are the same. Head and thorax are covered with close minute punctures; the latter has four rounded, slightly elevated tubers on the surface, besides one, more conical, on each side, a little before the middle. The elytra are less broad at the shoulders, and are singly somewhat narrowed towards the apex, the latter briefly truncated. The dilatation of the apex of the posterior tibiæ forms an obtusely angular, compressed lobe. The claw-joints of the tarsi are dilated almost as much as in Logisticus rostratus.

Madagascar.

Bartholomew Road, Kentish Town :

March, 1879.

Is Dytiscus latissimus found in North America?-My regretted friend, the ate G. R. Crotch, has recorded this species as North American, chiefly, I believe, from information furnished to him by myself. In the Trans. Am. Ent. Soc. (December, 1876, p. 250), Dr. Horn has published the following note on the subject :"Dytiscus latissimus, Lin., should not be included in our lists. I am satisfied that the species was never alive on this side of the Atlantic, and from the number of 


\section{$2 \mathrm{BHL}$ Biodiversity Heritage Library}

Bates, Henry Walter. 1879. "A new Eudromus, and three new species of Lepturidæ from Madagascar." The Entomologist's monthly magazine 15, 250-252. https://doi.org/10.5962/bhl.part.22018.

View This Item Online: https://www.biodiversitylibrary.org/item/36482

DOI: https://doi.org/10.5962/bhl.part.22018

Permalink: https://www.biodiversitylibrary.org/partpdf/22018

\section{Holding Institution}

Smithsonian Libraries

\section{Sponsored by}

Smithsonian

\section{Copyright \& Reuse}

Copyright Status: NOT_IN_COPYRIGHT

This document was created from content at the Biodiversity Heritage Library, the world's largest open access digital library for biodiversity literature and archives. Visit BHL at https://www.biodiversitylibrary.org. 